\title{
A Review on the Deposit Geology and Mineralization Mechanism of Tsumeb Polymetallic Deposit, Namibia
}

\author{
Regean Pumulo Pitiya1,2*, Lubang Jacob Peter ${ }^{1,2}$ \\ ${ }^{1}$ School of Geoscience and Info-Physics, Central South University, Changsha, China \\ ${ }^{2}$ The Key Laboratory of Nonferrous Metal Mineralization Prediction and Geological Environment Detection of Ministry of \\ Education (Central South University), Changsha, China \\ Email: ^regeanpitiya@yahoo.com
}

How to cite this paper: Pitiya, R.P. and Peter, L.J. (2021) A Review on the Deposit Geology and Mineralization Mechanism of Tsumeb Polymetallic Deposit, Namibia. Open Access Library Journal, 8: e8121. https://doi.org/10.4236/oalib.1108121

Received: October 27, 2021

Accepted: November 20, 2021

Published: November 23, 2021

Copyright $\odot 2021$ by author(s) and Open Access Library Inc.

This work is licensed under the Creative Commons Attribution International License (CC BY 4.0).

http://creativecommons.org/licenses/by/4.0/

\begin{abstract}
The Tsumeb polymetallic deposit of Otavi Mountain Land (OML), Namibia, is a prominent deposit of remarkable and complex mineral species with the accreditation of about 337 valid minerals. A total of 72 species of these minerals are of Tsumeb as the type of locality. The deposit was first prospected in 1893 by the South West Africa Company and it was mined from the year 1897 to 1996 , yielding a total of about $30 \mathrm{Mt}$ of ore with the grade of $10 \% \mathrm{~Pb}$, $4.3 \% \mathrm{Cu}$, and $3.5 \% \mathrm{Zn}$ along with ore minerals of $\mathrm{As}, \mathrm{Sb}, \mathrm{Ag}$, $\mathrm{Cd}$, and $\mathrm{Au}$. The orebody also typifies the largest renowned single sulfidic accumulation of germanium (Ge). However, like many other deposits, the Tsumeb copper deposit has been exhausted. Hence, re-assessment of ore reserve and exploration is a crucial practice in the discovery of new mineral resources and occurrences. This practice requires extensive understanding of the geological characteristics and metallogenic mechanisms of the parent/exhausted ore deposit as a reference model. In this paper, we presented a summary description of the Tsumeb deposit (polymetallic Copper deposit) of the Otavi Mountain Land (OML), Namibia, with the main focus on the regional geological background, deposit geology and ore mineralization mechanism.
\end{abstract}

\section{Subject Areas}

Geology

\section{Keywords}

Tsumeb, Otavi Mountain Land (OML), Mineralization, Damara Orogen, Neoproterozoic 


\section{Introduction}

Tsumeb is a town of about 19,000 residents and one of the big towns in Oshikoto region, located in northeast Namibia, on the South West side of Africa, roughly $500 \mathrm{~km}$ to the North of the capital city, Windhoek (Figure 1) [1] [2]. The town is characterized by a hot semi-arid climate, with hot summers and mild winters with average annual precipitation of $528 \mathrm{~mm}$. The Tsumeb polymetallic Copper deposit is one of the critical carbonate-hosted manifestations of $\mathrm{Cu}, \mathrm{Pb}, \mathrm{Zn} \mathrm{mi-}$ neralization within the Otavi Mountain Land (OML) [3]. This deposit is a prominent deposit of remarkable and complex elements with the accreditation of about 337 valid minerals of which 72 of these minerals are of Tsumeb type-locality [4] [5] [6] [7]. The deposit was first prospected in 1893 by the South West Africa Company, commercially mined from the year 1897 to 1996, yielding a total of about $30 \mathrm{Mt}$ of ore with the grade of $10 \% \mathrm{~Pb}, 4.3 \% \mathrm{Cu}$, and $3.5 \% \mathrm{Zn}$ along with minerals of $\mathrm{As}, \mathrm{Sb}, \mathrm{Ag}, \mathrm{Cd}, \mathrm{Ge}$ and $\mathrm{Au}$ [8]. Extraction of minerals from the Tsumeb deposit, copper minerals in particular has a history prior to the year 1897. The extraction activities were done by ancient people smelting copper, locally in the vicinity of Tsumeb. The smelting of copper was a common exercise in the Bergdama tribe, the Herero and Ovambo people [9] [10] [11]. For indigenous miners, the green tint of malachite identified copper-bearing deposits

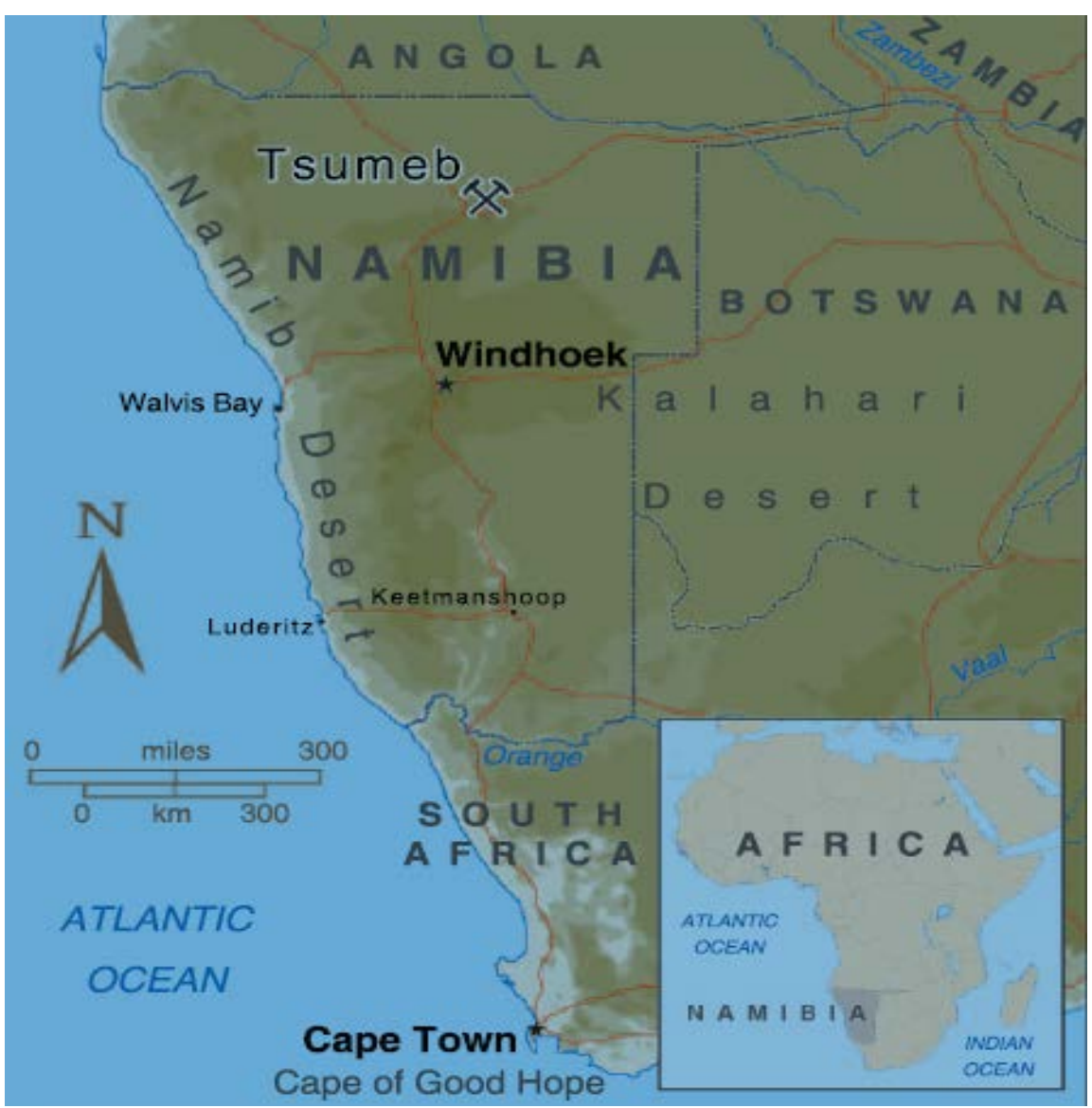

Figure 1. Map showing Tsumeb in Namibia (modified from Cairncross, 2017). 
from other rocks and they used it for a variety of purposes including making jewelry, weapons, and trading it in exchange for livestock. Still, present-day evidence shows that ancient smelting activities are widespread all over the Otavi Mountain Land, with the pattern and methods employed being alike to those used prior to $500 \mathrm{AD}$ in Central Africa [12] [13] [14]. The ore deposit is well-known and was one of the major producers of base metal in Africa [15], in particular due to its profound high quality ore throughout its production lifespan [16] [17]. The high grade ore at the time meant that a greater proportion of the ore was sent directly to the smelter without undergoing mineral enrichment stage. The deposit output was moderate until 1990 when the price of copper declined, along with eventuality of strikes at the mine. The labour strikes halted operations at the mine which lead to flooding of major equipment thus its closure in 1996 [18]. In this paper, we present a summary of the Tsumeb deposit (polymetallic Copper deposit) of the Otavi Mountain Land (OML), Namibia, based on selected literature sources, with the main focus on the regional geological background, deposit geology and ore mineralization. The primary objectives of this study are to ascertain the nature of geological and tectonic events, and the origin of ore-forming elements, as well as to better understand the ore-forming process and mineral precipitation mechanism of the Tsumeb deposit.

\section{Regional Geology and Tectonic Evolution}

The Tsumeb deposit is located within the Otavi Mountain land (OML), a mineral zone spanning about $10,000 \mathrm{~km}^{2}$ of northern Namibia, forming part of the Northern Carbonate Platform of the Pan African Damara Orogen [19] [20] [21]. There are more than $600 \mathrm{Cu}-\mathrm{Pb}-\mathrm{Zn}-\mathrm{V}$ deposits and occurrences reported in OML [22]. The Damara Orogen is a late-Proterozoic orogenic belt of Pan African age, situated between the ancient landforms of the Congo and Kalahari cratons [23] [24] [25] [26] [27]. It accommodates various species of sulphide ( $\mathrm{Pb}-\mathrm{Cu}-\mathrm{Zn}$ ore deposit dominated by "oxidized" $\mathrm{Pb}, \mathrm{Cu}$ and $\mathrm{Zn}$ ore minerals) and non-sulphide occurrences [28] [29]. The formation of the Damara Orogen is characterized by multifarious geotectonic episodes which can be broadly summarized into earlier deposition of a geosynclinals sequence estimated at 900 to $650 \mathrm{Ma}$, triggered by the separation of the Kalahari, Congo and proto-South American cratons [30] [31]. The rifting allowed the deposition that lead to formation of the Damara Orogen, which was then tailed by episodes of compression [32] [33] [34].

The Damara orogeny sedimentary rocks' texture and composition indicate that they formed in a cold to temperate climate. Two global ice periods, the so called "Snowball Earth", disrupted regular sedimentation hundreds of millions of years ago, when massive glaciers covered the land. When the glaciers eventually retreated and temperatures rose again, characteristic deposits of glacial debris accumulated, allowing rock units to be associated between different regions of the Damara Orogen. However, Eyles \& Januszczak (2007) [35] argue 
based on sedimentological analyses of specific outcrops in Namibia that there is no distinct indication of catastrophic Snowball Earth-type glaciations. In addition, the findings of Eyles and Januszczak (2007) [35] support the idea of tectonic dominance over sedimentation, which is linked to recurring occurrences of faulting and slope failure. In the Damara Orogen, mineralization regions formed all the way through and post orogenic processes due to multifarious interactions between magma, hydrothermal solutions, and sediments [36]. The northern part (arm) of the Damara Orogen is identified as the Kaoko Belt, whereas the southern part overlying the Namaqua Metamorphic Complex, which consists of meta-sediments in southern Namibia, is identified as the Gariep Belt (Figure 2) [37] [38]. Detailed descriptions about the Damara Orogen are documented by Joseph, Richard, Ben, \& Rudolph (2008) [30] and Haack \& Martin (1983) [39].

\section{Regional Stratigraphy and Structure}

Within the OML, the Neoproterozoic siliciclastic and carbonate successions of the Damara Supergroup of the Damara Belt are separated into three groups. Lithologically, the groups from bottom to top are: 1) Nosib Group, which are volcanic and clastic sediments, reaches up to $1200 \mathrm{~m}$ in thickness [40];2) Otavi Group, $4800 \mathrm{~m}$ in thickness with predominance of carbonates, estimated to be deposited between 750 and $545 \mathrm{Ma}$ and; 3) Mulden Group, deposition or age constrained between 580 and $541 \mathrm{Ma}$, which are clastic molasse-type sediments [41].

The Otavi group is subdivided into the Tsumeb and Abenab sub-groups. The three groups of sedimentary strata are supported by basement rocks made up of granite, gneiss, and a mafic complex that is poorly exposed. The Otavi Mountain Land's regional structure is made up of east-west-trending folds that are overprinted by a second folding phase that produces northward veering recumbent folds. Furthermore, lower green-schist to prehnite-pumpellyite facies metamorphisms have occurred in the Otavi mountain land layers.

\section{Geology and Mineralization of the Tsumeb Deposit}

Stratigraphically, the Tsumeb deposit rests in the upper section of the Otavi group, (Figure 3 and Figure 4). The ore deposit is a polymetallic pipe-like body (Figure 5 and Figure 6) emplaced at $530 \pm 11 \mathrm{Ma}$ [42] [43]. The dolomite and limestone of the Neoproterozoic age (a period between 1 billion years to 542 million years ago) are the major lithology. The host rocks of the Tsumeb pipe are similar to that of northern Arizona breccia pipe deposit [44]. The development mechanism of the pipe-like body structure of the ore was a result of solution pipe and karst activities [45] [46]. The action of karst formation driven by meteoric water can be simply described as follow: meteoric water picks up carbon dioxide from the atmosphere and soil respiration (produced by soil organisms), the combination result is a weak carbonic acid solution which then dissolves the carbonaceous rocks along the flow path to a certain extent, thus the creating cleavages, cavities and sinkholes [47]. 


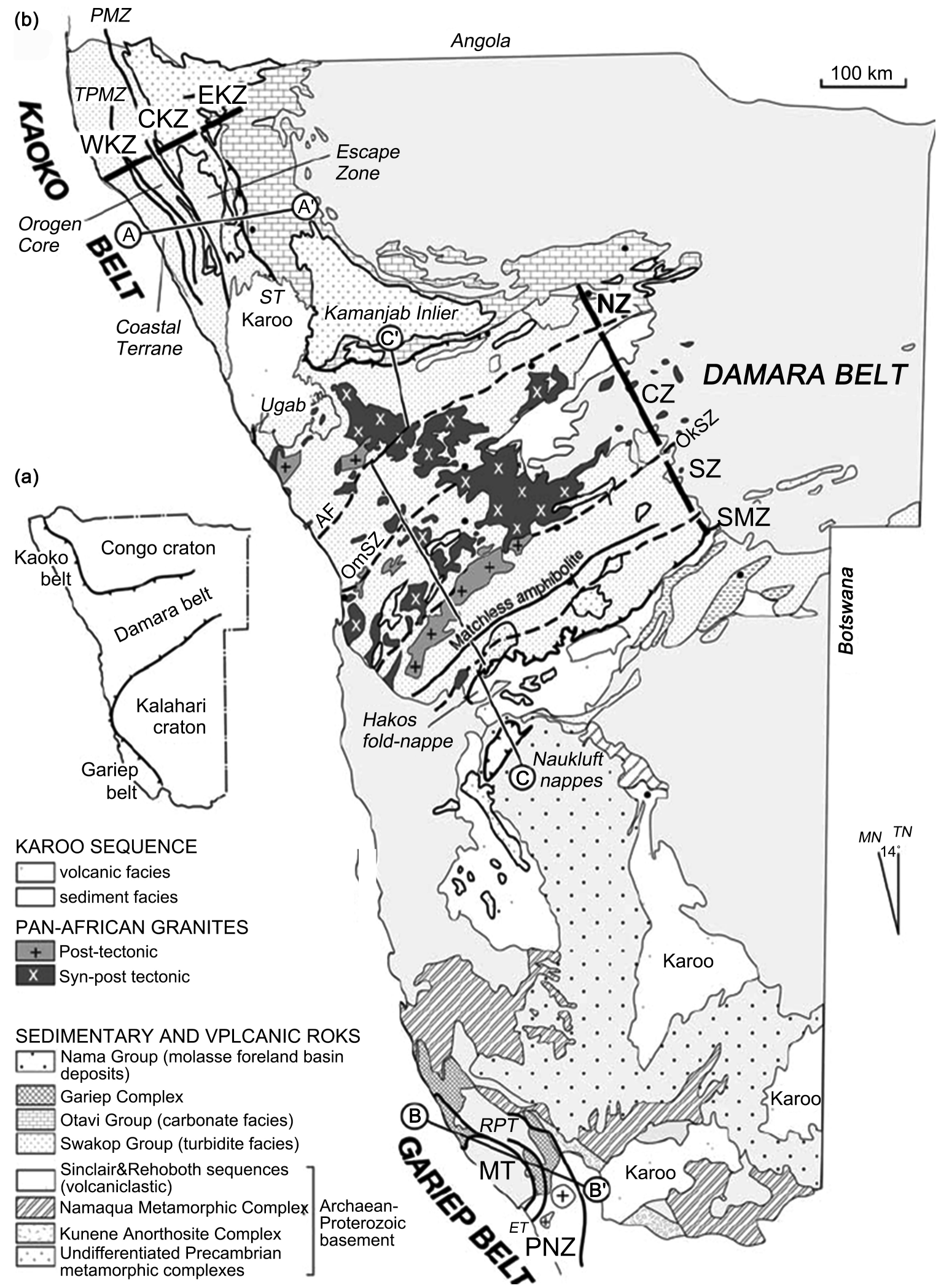

Figure 2. Geological map of the Damara Orogen: (a) Sections of the Damara Orogen with Damara belt located between the Congo and Kalahari cratons, northern arm identified as the Kaoko belt and the southern arm as the Gariep belt, (b) Depiction of the distribution of the Karoo sequence, Pan-African granites, sedimentary and volcanic rocks (adapted from Joseph, Richard, Ben, \& Rudolph, 2008). 


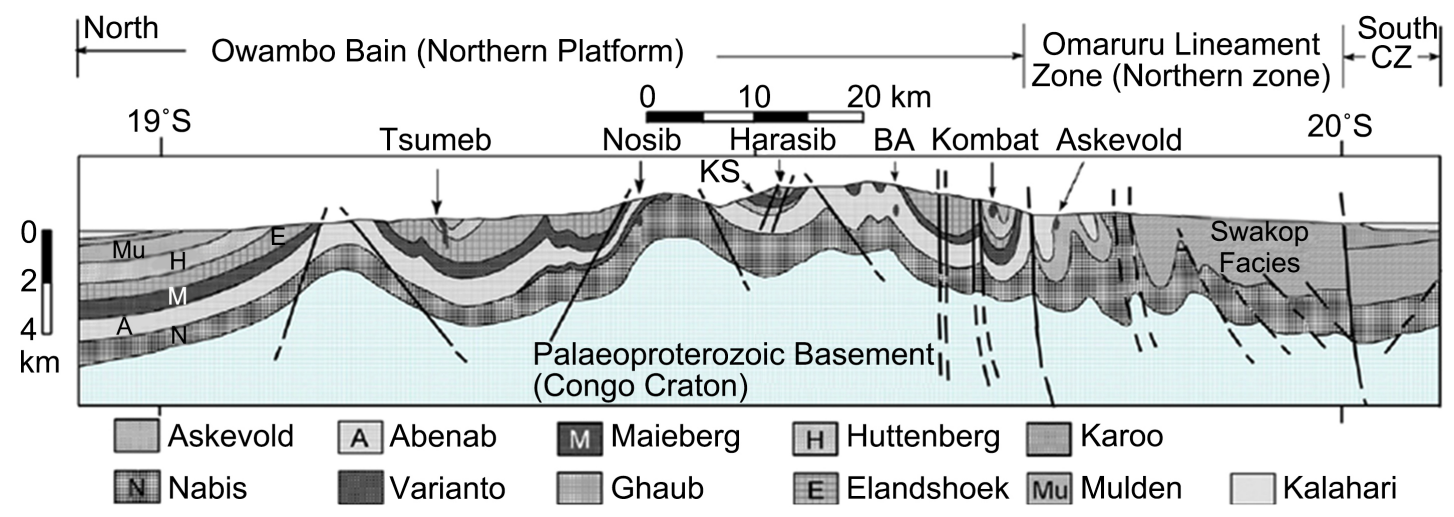

Figure 3. The north-south section across the OML depicting major structures, deposits and prospects (adapted from Kamona \& Günze, 2007).

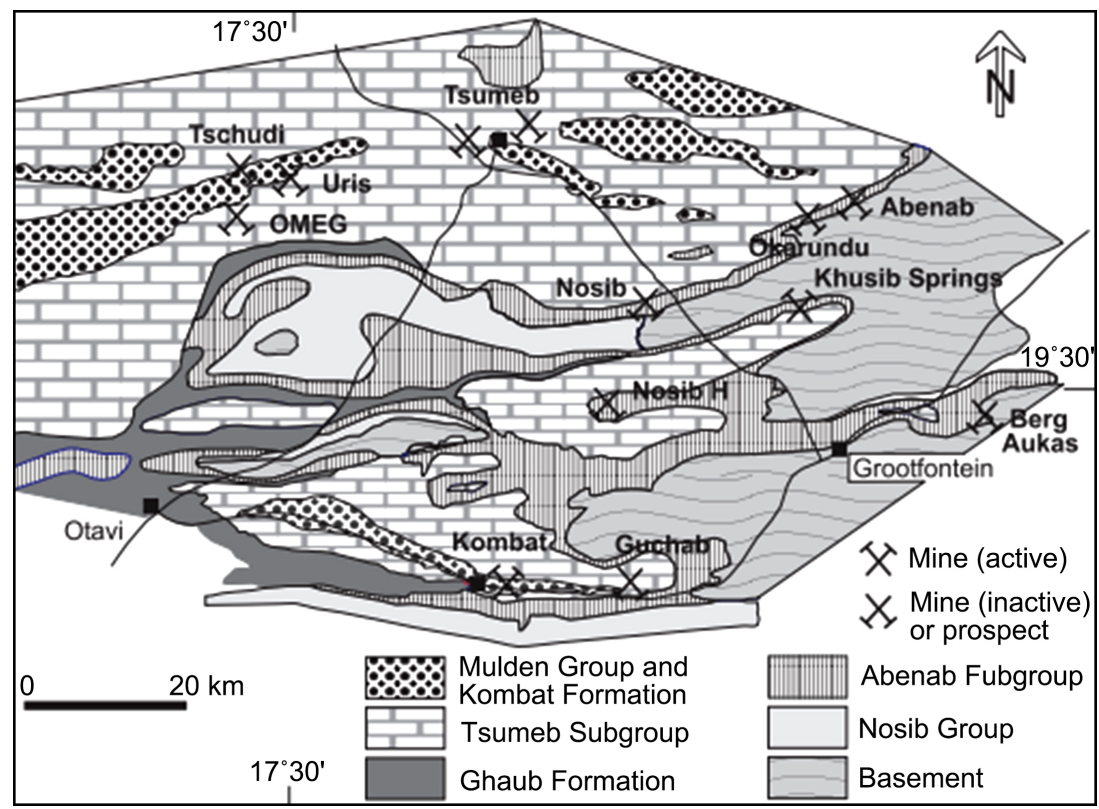

\begin{tabular}{|c|c|c|c|c|}
\hline Group & Subgroup & \multicolumn{2}{|l|}{ Formation } & Lithology \\
\hline \multirow{3}{*}{ Mumlden } & & \multicolumn{2}{|l|}{ Owambo } & $\begin{array}{l}\text { Pelite, marl, } \\
\text { carbonate }\end{array}$ \\
\hline & & \multicolumn{2}{|l|}{ Kombat } & Shale \\
\hline & & \multicolumn{2}{|l|}{ Tschudi } & Arenite \\
\hline \multirow{8}{*}{$\begin{array}{l}\text { Otavi } \\
\qquad 580 \mathrm{Ma}\end{array}$} & \multirow{5}{*}{ Tsumeb } & \multirow{2}{*}{ Hüttenberg } & \multirow{2}{*}{$\begin{array}{l}78 \\
77 \\
76 \\
T 5\end{array}$} & Dolomite, Pelite \\
\hline & & & & \multirow{2}{*}{ Dolomite, Chert } \\
\hline & & Elandshoek & 15 & \\
\hline & & Maieberg & $\begin{array}{l}\text { T3 } \\
\text { T2 }\end{array}$ & $\begin{array}{l}\text { Dolomite } \\
\text { Limestone }\end{array}$ \\
\hline & & \multirow{2}{*}{\multicolumn{2}{|c|}{$\begin{array}{l}\text { Ghaub } \\
\text { Auros }\end{array}$}} & Diamictite \\
\hline & \multirow{4}{*}{ Abenab } & & & Carbonate, Pelite \\
\hline & & \multicolumn{2}{|l|}{ Gauss } & \multirow{2}{*}{ Dolomite } \\
\hline & & \multicolumn{2}{|l|}{ Berg Aukas } & \\
\hline $750 \mathrm{Ma}$ & & \multicolumn{2}{|l|}{ Chuos } & Diamictite \\
\hline \multirow{2}{*}{ Nosib } & & \multicolumn{2}{|l|}{ Askevold } & Volcanics \\
\hline & & \multicolumn{2}{|l|}{ Nabis } & Clastics \\
\hline \multicolumn{4}{|c|}{ Grootfontein Basement Complex } & \\
\hline
\end{tabular}

Figure 4. Geological map of the Otavi Mountain Land, with major mines and prospects (upper part of the figure), as well as table of Groups of OML (lower part of the figure) (modified from Melcher, 2003): Note, the OML is divided into three groups with distinct Formations and Lithology. 
(a)

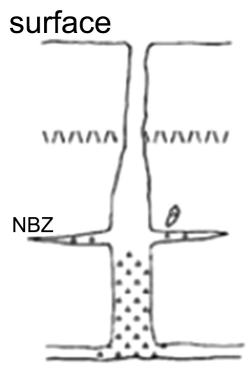

(d)

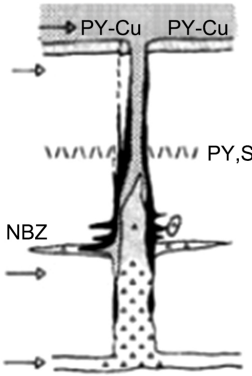

(b)

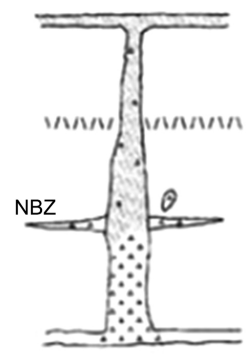

(e)

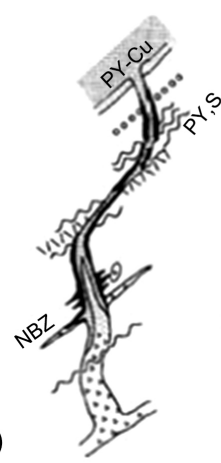

(c)

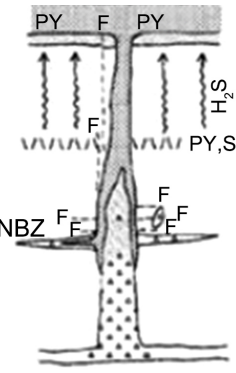

\section{LEGEND}

sandstone siltstone $\}$ Mulden Group

dolostone and limestone

anhydrite gypsum: zone T7 Otavi

North Break zone

.. breccia

F massive ore, including mantos

PY SPY-Cu pyrite, native sulphur,

pyrite-copper mineralization

-.-F fracture

thrust zone

$\rightarrow$ ore fluid flow

Figure 5. Tsumeb deposit development sequence (modified from Maiden \& Hughes, 2000). (a) Development of a solution pipe partially infused with sedimentary and strata-bound breccia. (b) Infilling of karstic cavities and solution pipe with sandstone from the overlying Mulden group. (c) Subsidence of the pipe's sedimentary column. (d) Flow of fluids released from the Pan-African Damara's belt orogeny and deposition of primary minerals ( $\mathrm{Pb}-\mathrm{Cu}-\mathrm{Zn}$ sulphide minerals) into the pipe. (e) Episodes of folding and thrusting of the pipe mineralization.

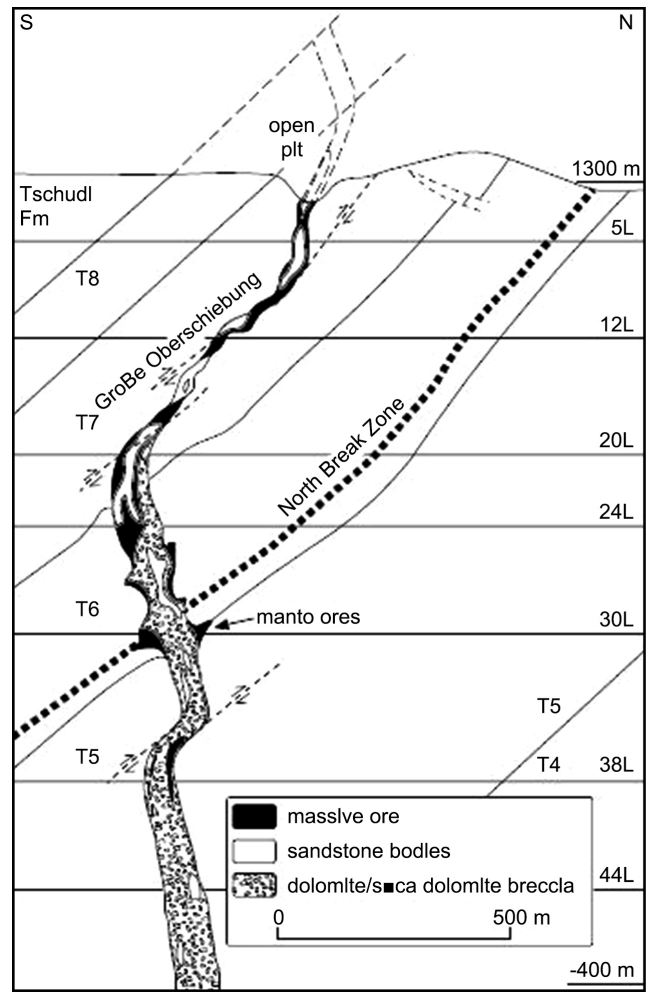

\begin{tabular}{|l|}
\hline Key \\
Massive ores \\
Sandstone bodies \\
- Dolomite/dolomite breccia \\
Fm: Formation, L: level, m: meter \\
T: Tertiary Period (associated to \\
lithology)
\end{tabular}

Figure 6. Geological cross-sectional view of the Tsumeb pipe deposit (adapted from Laukamp, 2006): Note T5-T8 signifies Dolomite units; white areas signify sandstone and the dark structure being the high grade oxide and sulphide ore. 
Another rare situation is when surface water rich in oxygen or underground water reacts with sulfides such as pyrite and hydrogen sulfide to form sulfuric acid solution which also dissolves the carbonatites, leaving behind a cavity. The pipe-like cavity of the Tsumeb is believed to have been infilled with the sandstone from the overlying Mulden group, thus forming the host of the mineralization [48]. According to Chetty \& Frimmel (2000) [49], fluids released during Pan-African orogeny in the Damara Belt's more severely deformed interior zones are thought to be the source of Tsumeb mineralization. Base metal sulphide precipitation took place in regions of relatively increased porosity afforded by karst features in the carbonaceous structure (cavities and cleavages) when fluids of high salinity reached the carbonate platform after incorporating great amounts of base metals [50] [51]. Large scale alteration such as silicification, calcification and host rock argillization as well as the presence of hydrothermal carbonate-veins are some of the noticed features of the pipe mineralization [52] [53]. A diverse species of minerals such as Copper, Lead, Zinc, Silver, Antimony, Cadmium, Cobalt, Germanium, Gallium, Gold, Iron, Mercury, Molybdenum, Nickel, Tin, Tungsten and Vanadium were compositional elements of the pipe mineralization [54] [55] [56].

The recognized ore emplacement controls comprise the core breccia, interrupted circular fracture, and feldspathic sandstone internal mass [57] [58]. The ore body bound to the pipe was estimated to having dimensions of 15 by $120 \mathrm{~m}$ cross-section [58]. It was a steeply dipping ore body that extended from the surface to a depth of approximately 1700 meters. The Tsumeb pipe deposit contained high mineralized pods, large lenses (Manto Ore) and small veins predominately emplaced in arcuate and marginal fractures. It is also established that minerals forming low grade ore with large tonnage were disseminated in altered rock formations. According to Bowell \& Mocke (2018) [1], the Tsumeb orebody's large marginal ores held up to $40 \%$ total metal $(\mathrm{Pb}+\mathrm{Cu}+\mathrm{Zn})$ concentration. There was a noticeable fracture zone extending from the surface intersecting the sulfide ore pipe at a depth of approximately $900 \mathrm{~m}$ [59] [60]. This fracture was a conduit for meteoric water, which created a lower oxidized zone in the sulfide ore [61] [62] [63]. Within the pipe deposit, three oxidation zones had been identified containing secondary minerals derived from the alteration of primary sulfides minerals. These oxidation zones occurred from surface down to level 12 (360 $\mathrm{m}$ below surface) [64], from level $25(750 \mathrm{~m})$ to $35(1150 \mathrm{~m})$, and below level $42(1380 \mathrm{~m})$. At the level 25 , the primary sulfide orebody was slightly altered. The second oxidation zone below level 25 was characterized by perfectly developed secondary minerals. At the intersection (Level 28 and 29) of pipe and North Break Zone "NBZ", there was a development of rich sulfides (secondary minerals) [52] [65]. The third oxidation zone, which was only observed in the last stage of mining, was typified by a mixed sulfide-oxide mineralization and it only hosted partially oxidized arsenites (leiteite) [1] [66].

\section{Concluding Remarks}

The ore formation of the Tsumeb polymetallic deposit with its diverse mineral- 
ogy composition was a result of the Pan-African Damara orogenic process. The orogenic process was essential for mineralization in OML as it activated various interactions between magma, hydrothermal solutions, and sediments. In particular, the fluids liberated during orogenic processes in the Damara Belt's more severely deformed inner zones were the principal source of Tsumeb mineralization. Base metal sulphide precipitation occurred in karst structures of the carbonate rocks that provided considerably enhanced porosity. The Tsumeb mineralization is classified into four types, 1) The Oxide ores, which are supergene ores within the pipe's upper part, as well as in the oxidation zones; 2) Disseminated ores, which are hosted in unaltered to altered bedded dolomite and dolomite breccias as well as by feldspathic sandstone; 3) Manto ores, which are wing like extensions attached to the pipe; and 4) Massive peripheral ore, marginal ores which held up to $40 \%$ total metal $(\mathrm{Pb}+\mathrm{Cu}+\mathrm{Zn})$ concentration. In general, according to the climatic setting, geological nature, and history of mineral extractions of OML as well as the documented mineralization mechanism of Tsumeb orebody as a representative of the OML, there is potential for high-value mineralization and underground water resources in the OML. The potential high-value mineralization is also associated with tectonic events including rifts, and thrust and folds belt systems, characteristic of OML. These resources or potential reserves can in the future be delineated by deployment of extensive integrated geophysical prospecting and exploration techniques.

\section{Acknowledgements}

We appreciate the opportunity to discuss with Professor Chen Rujun of the School of Geoscience and Info-Physics, Central South University.

\section{Conflicts of Interest}

The authors declare no conflicts of interest.

\section{References}

[1] Bowell, R. and Mocke, H. (2018) Minerals New to Tsumeb. Communications of the Geological Survey of Namibia, 19, 20-46.

[2] Cairncross, B. (2017) The Where of Mineral Names: Tsumebite, Tsumeb Mine, Namibia. Rocks \& Minerals, 92, 466-472. https://doi.org/10.1080/00357529.2017.1331402

[3] Pirajno, F. and Joubert, B. (1993) An Overview of Carbonate-Hosted Mineral Deposits in the Otavi Mountain Land, Namibia: Implications for Ore Genesis. Journal of African Earth Sciences, 16, 265-272. https://doi.org/10.1016/0899-5362(93)90048-U

[4] Melcher, F. (2003) The Otavi Mountain Land in Namibia: Tsumeb, Germanium and Snowball Earth. Mitteilungen der Österreichischen Mineralogischen Gesellschaft, 148, 413-435.

[5] Robert, B.J. (2014) Hydrogeochemistry of the Tsumeb Deposit: Implications for Arsenate Mineral Stability. Reviews in Mineralogy and Geochemistry, 79, 589-627. https://doi.org/10.2138/rmg.2014.79.14 
[6] Moore, T. (1999) Tsumeb: A Unique Mineral Locality. The Mineralogical Record Inc., Bowie.

[7] Cook, R.B., Nicolson, B.E. and Bruce, I.R. (2002) Tsumeb-200. Rocks \& Minerals, 77, 18-24. https://doi.org/10.1080/00357529.2002.9926651

[8] Chetty, D. and Frimmel, H. (2000) The Role of Evaporites in the Genesis of Base Metal Sulphide Mineralisation in the Northern Platform of the Pan-African Damara Belt, Namibia: Geochemical and Fluid Inclusion Evidence from Carbonate Wall Rock Alteration. Mineralium Deposita, 35, 364-376. https://doi.org/10.1007/s001260050247

[9] Nujoma, S. (2009) Copper-Its Geology and Economic Impact on Development in Namibia, Zambia and the Democratic Republic of the Congo. M.Sc Thesis, University of Namibia, Windhoek, 22.

[10] Weatherly International (2013) Central Operations Executive Summary. Weatherly International, Windhoek.

[11] Cairncross, B. and Moir, S. (1996) The Onganja Mining District: Namibia. The Mineralogical Record, 27, 85-98.

[12] Cairncross, B. (1997) The Otavi Mountain Land Cu-Pb-Zn-V Deposits, Namibia. Mineralogical Record, 28, 109-130.

[13] Weatherly Mining Namibia (2016) Tschudi Copper Mine Technical Report. Weatherly Mining Namibia, Windhoek.

[14] Emslie, D.P. (1980) The Mineralogy and Geochemistry of the Copper Lead and Zinc Sulphides of the Otavi Mountainland (No. NIM-2056). National Institute for Metallurgy, Mpumalanga.

[15] Meyer, M.C.G. (1953) The Importance of Outside Mining in Southern Africa. Journal of the Southern African Institute of Mining and Metallurgy, 53, 345-359.

[16] Charles, S.B. and Geier, B.H. (1957) The Paragenetic Relationships of Germanite and Renierite from Tsumeb, South West Africa. Economic Geology, 52, 612-631.

[17] Cooper, M.A., Abdu, Y.A., Ball, N.A., Hawthorne, F.C., Back, M.E., et al. (2012) Ianbruceite, Ideally $\left[\mathrm{Zn}_{2}(\mathrm{OH})\left(\mathrm{H}_{2} \mathrm{O}\right)\left(\mathrm{AsO}_{4}\right)\right]\left(\mathrm{H}_{2} \mathrm{O}\right)_{2}$, a New Arsenate Mineral from the Tsumeb Mine, Otjikoto (Oshikoto) Region, Namibia: Description and Crystal Structure. Mineralogical Magazine, 76, 1119-1131. https://doi.org/10.1180/minmag.2012.076.5.05

[18] Jones, R.T. and Mackey, P.J. (2015) An Overview of Copper Smelting in Southern Africa. Incorporating the 8 th Southern African Base Metals Conference Livingstone, Zambia, 6-8 July 2015, 499-504.

[19] Misiewicz, J.E. (1988) The Geology and Metallogeny of the Otavi Mountain land, Damara Orogen, SWA/Namibia, with Particular Reference to the Berg Aukas Zn-Pb-V Deposit: A Model of Ore Genesis. Thesis, Rhodes University, Grahamstown.

[20] Kamona, A. and Günze, A. (2007) Stratigraphy and Base Metal Mineralization in the Otavi Mountain Land, Northern Namibia-A Review and Regional Interpretation. Gondwana Research, 11, 396-413. https://doi.org/10.1016/j.gr.2006.04.014

[21] Hoffman, P.F., Halverson, G.P., Schrag, D.P., Higgins, J.A., Domack, E.W., Macdonald, F.A., et al. (2021) Snowballs in Africa: Sectioning a Long-Lived Neoproterozoic Carbonate Platform and Its Bathyal Foreslope (NW Namibia). Earth-Science Reviews, 219, Article ID: 103616. https://doi.org/10.1016/j.earscirev.2021.103616

[22] Kampunzu, A.B., Cailteux, J.L.H., Kamona, A.F., Intiomale, M.M. and Melcher, F. (2009) Sediment-Hosted $\mathrm{Zn}-\mathrm{Pb}-\mathrm{Cu}$ Deposits in the Central African Copperbelt. Ore 
Geology Reviews, 35, 263-297. https://doi.org/10.1016/j.oregeorev.2009.02.003

[23] Ben, G., David, G. and Hand, M. (2004) Variation in Metamorphic Style along the Northern Margin of the Damara Orogen, Namibia. Journal of Petrology, 45, 1261-1295.

[24] Maria, B., Rosario, T., Noreen, J.E., Carsten, L., Jens, S. and Thilo, B. (2007) Genesis of Vanadium Ores in the Otavi Mountainland, Namibia. Economic Geology, 102, 441-469. https://doi.org/10.2113/gsecongeo.102.3.441

[25] Hartnady, C., Joubert, P. and Stowe, C. (1985) Proterozoic Crustal Evolution in Southwestern Africa. Episodes, 8, 236-244.

https://doi.org/10.18814/epiiugs/1985/v8i4/003

[26] Nascimento, D.B., Ribeiro, A., Trouw, R.A.J., Schmitt, R.S. and Passchier, C.W. (2016) Stratigraphy of the Neoproterozoic Damara Sequence in Northwest Namibia: Slope to Basin Sub-Marine Mass-Transport Deposits and Olistolith Fields. Precambrian Research, 278, 108-125. https://doi.org/10.1016/j.precamres.2016.03.005

[27] Ministry of Mines and Energy (2017, May 4) Publications. http://www.mme.gov.na/files/publications/845 A4 Damara en.pdf

[28] Laukamp, C. (2006) Structural and Fluid System Evolution in the Otavi Mountainland (Namibia) and Its Significance for the Genesis of Sulphide and Nonsulphide Mineralisation. phD Dissertation, Ruprecht-Karls-Universität, Heidelberg.

[29] Mondillo, N., Herrington, R., Boyce, A., Wilkinson, C., Santoro, L. and Rumsey, M. (2018) Critical Elements in Non-Sulfide Zn Deposits: A Reanalysis of the Kabwe $\mathrm{Zn-Pb}$ Ores (Central Zambia). Mineralogical Magazine, 82, S89-S114. https://doi.org/10.1180/minmag.2017.081.038

[30] Gray, D.R., Foster, D.A., Meert, J.G., Goscombe, B.D., Armstrong, R., Trouw, R.A.J., et al. (2008) A Damara Orogen Perspective on the Assembly of Southwestern Gondwana. Geological Society, London, Special Publications, 294, 257-278. https://doi.org/10.1144/SP294.14

[31] Basson, I.J., McCall, M.J., Andrew, J. and Daweti, E. (2018) Structural Controls on Mineralisation at the Namib Lead and Zinc Mine, Damara Belt, Namibia. Ore Geology Reviews, 95, 931-944. https://doi.org/10.1016/j.oregeorev.2018.03.028

[32] Stanistreet, I.G., Kukla, P.A. and Henry, G. (1991) Sedimentary Basinal Responses to a Late Precambrian Wilson Cycle: The Damara Orogen and Nama Foreland, Namibia. Journal of African Earth Sciences (and the Middle East), 13, 141-156. https://doi.org/10.1016/0899-5362(91)90048-4

[33] Breitkopf, J.H. and Maiden, K.J. (1988) Tectonic Setting of the Matchless Belt Pyritic Copper Deposits, Namibia. Economic Geology, 83, 710-723. https://doi.org/10.2113/gsecongeo.83.4.710

[34] Prave, A.R. (1996) Tale of Three Cratons: Tectonostratigraphic Anatomy of the Damara Orogen in Northwestern Namibia and the Assembly of Gondwana. Geology, 24, 1115-1118. https://doi.org/10.1130/0091-7613(1996)024<1115:TOTCTA >2.3.CO;2

[35] Eyles, N. and Januszczak, N. (2007) Syntectonic Subaqueous Mass Flows of the Neoproterozoic Otavi Group, Namibia: Where Is the Evidence of Global Glaciation? Basin Research, 19, 179-198. https://doi.org/10.1111/j.1365-2117.2007.00319.x

[36] Frimmel, H.E. and Miller, R.M. (2009) Continental Rifting. Developments in Precambrian Geology, 16, 153-159. https://doi.org/10.1016/S0166-2635(09)01611-9

[37] Brandt, R. (1985) Preliminary Report on the Stratigraphy of the Damara Sequence and the Geology and Geochemistry of Damaran Granites in an Area between Walvis Bay and Karibib. Communications of the Geological Survey of South West Afri- 
cal Namibia, 1, 31-44.

[38] Schlüter, T. (2006) Namibia. In: Geological Atlas of Africa: With Notes on Stratigraphy, Tectonics, Economic Geology, Geohazards and Geosites of Each Country, Springer, Berlin, Heidelberg, 172-175. https://doi.org/10.1007/3-540-29145-8 41

[39] Haack, U. and Martin, H. (1983) Geochronology of the Damara Orogen-A Review. In: Martin, H. and Eder, F.W., Eds., Intracontinental Fold Belts, Springer, Berlin, 839-846. https://doi.org/10.1007/978-3-642-69124-9 36

[40] Miller, M.R. (2013) Comparative Stratigraphic and Geochronological Evolution of the Northern Damara Supergroup in Namibia and the Katanga Supergroup in the Lufilian Arc of Central Africa. Geoscience Canada, 40, 118-140.

https://doi.org/10.12789/geocanj.2013.40.007

[41] Germs, G.J., Miller, R.M., Frimmel, H.E. and Gaucher, C. (2009) Syn- to Late-Orogenic Sedimentary Basins of Southwestern Africa. Developments in Precambrian Geology, 16, 183-203. https://doi.org/10.1016/S0166-2635(09)01613-2

[42] Will, T.M., Miller, R.M. and Frimmel, H.E. (2010) Orogenic Tectono-Thermal Evolution. Developments in Precambrian Geology, 16, 205-218.

https://doi.org/10.1016/S0166-2635(09)01614-4

[43] Haest, M. and Muchez, P. (2011) Stratiform and Vein-Type Deposits in the Pan-African Orogen in Central and Southern Africa: Evidence for Multiphase Mineralisation. Geologica Belgica, 14, 23-44.

[44] Wenrich, K.J., Van Gosen, B.S., Finch, W.I. and du Bray, E.A. (1995) Solution-Collapse Breccia Pipe U Deposits. In: du Bray, E.A., Preliminary Compilation of Descriptive Geoenvironmental Mineral Deposit Models, United States Geological Survey, Reston, 244-251.

[45] Readdy, L.A. (1972) Economic Geology and Photogeology of the Tsumeb Area, South West Africa. M.Sc Thesis, University of Arizona, Tucson.

[46] Hughes, M.J., Welke, H.J. and Allsopp, H.L. (1984) Lead Isotopic Studies of Some Late Proterozoic Stratabound Ores of Central Africa. Precambrian Research, 25, 137-139. https://doi.org/10.1016/0301-9268(84)90029-9

[47] De Waele, J. (2017) Karst Processes and Landforms. In: Richardson, D., Castree, N., Goodchild, M.F., Kobayashi, A., Liu, W. and Marston, R.A., Eds., The International Encyclopedia of Geography, John Wiley \& Sons, Hoboken. https://doi.org/10.1002/9781118786352.wbieg0968

[48] Schneider, J., Boni, M., Laukamp, C., Bechstädt, T. and Petzel, V. (2008) Willemite $\left(\mathrm{Zn}_{2} \mathrm{SiO}_{4}\right)$ as a possible $\mathrm{Rb}-\mathrm{Sr}$ Geochronometer for Dating Nonsulfide $\mathrm{Zn}$-Pb Mineralization: Examples from the Otavi Mountainland (Namibia). Ore Geology Reviews, 33, 152-167. https://doi.org/10.1016/j.oregeorev.2006.05.012

[49] Chetty, D. and Frimmel, H. (2000) The Role of Evaporites in the Genesis of Base Metal Sulphide Mineralisation in the Northern Platform of the Pan-African Damara Belt, Namibia: Geochemical and Fluid Inclusion Evidence from Carbonate Wall Rock Alteration. Mineralium Deposita, 35, 364-376. https://doi.org/10.1007/s001260050247

[50] Sohnge, P.G. (1974) Sedimentary Ore Deposits: A Review of Research Trends. South African Journal of Geology, 77, 159-168.

[51] Southwood, M. and Robison, J. (2016) Dolomite "Casts" and Epimorphs from Tsumeb. Namibia. Rocks \& Minerals, 91, 334-345. https://doi.org/10.1080/00357529.2016.1172174

[52] Borg, G. (2009) The Influence of Fault Structures on the Genesis of Supergene Zinc Deposits. Society of Economic Geologists Special Publication, 14, 121-132. 
https://doi.org/10.5382/SP.14.11

[53] Pirajno, F., Kinnaird, F.A., Fallick, A.E., Boyce, A. and Petzel, V. (1992) A Preliminary Regional Sulphur Isotope Study of Selected Samples from Mineralised Deposits of the Damara Orogen, Namibia. Communications of the Geological Survey of Namibia, 8, 87-104.

[54] Mapani, B., Rainer, E., Lothar, H., Gabi, S.K., Rosina, L., Mukuve, Z., Norwel, M., Shopala, U., Eline, N., William, A., Florence, S. and Maria, M. (2014) Contamination of Agricultural Products in the Surrounding of the Tsumeb Smelter Complex. Communications of the Geological Survey of Namibia, 15, 92-110.

[55] Reid, A. and de Beer, J. (2016) Geophysics in the Tsumeb Area, Namibia. In: de Beer, J., Ed., The History of Geophysics in Southern Africa, African Sun Media, Stellenbosch, 452. https://doi.org/10.18820/9781920689810

[56] Hazen, R.M., Hummer, D.R., Hystad, G., Downs, R.T. and Golden, J.J. (2016) Carbon Mineral Ecology: Predicting the Undiscovered Minerals of Carbon. American Mineralogist, 101, 889-906. https://doi.org/10.2138/am-2016-5546

[57] Maiden, K. and Hughes, M. (2000) Mount Isa and Tsumeb: A Comparative Metallogenic Study. Communications of the Geological Survey of Namibia, 12, 191-202.

[58] Allsopp, H.L. and Ferguson, J. (1970) Measurements Relating to the Genesis of the Tsumeb Pipe, South West Africa. Earth and Planetary Science Letters, 9, 448-453. https://doi.org/10.1016/0012-821X(70)90012-9

[59] Jones, R.W. (1985) Featured Mineral at the 1985 Tucson Show: Dioptase the Emerald Copper. Rocks \& Minerals, 60, 5-8. https://doi.org/10.1080/00357529.1985.11764359

[60] Desautels, P.E. (1991) Some Thoughts about Azurite. Rocks \& Minerals, 66, 14-23. https://doi.org/10.1080/00357529.1991.11761595

[61] Theron, S.J. (1994) The North Break Zone of the Late Precambrian Otavi Carbonate Platform Sequence in Namibia: Stratigraphic Setting, Petrography and Relationship with Tsumeb $\mathrm{Cu}-\mathrm{Pb}-\mathrm{Zn}$ Deposit. M.Sc Thesis, Rand Afrikaans University, Johannesburg.

[62] Bernstein, L.R. (1985) Germanium Geochemistry and Mineralogy. Geochimica et Cosmochimica Acta, 49, 2409-2422. https://doi.org/10.1016/0016-7037(85)90241-8

[63] Southwood, M. (2016) Connoisseur's Choice: Reinerite, Tsumeb, Namibia. Rocks \& Minerals, 91, 346-351. https://doi.org/10.1080/00357529.2016.1172175

[64] Southwood, M. (2018) Wulfenite from Tsumeb, Namibia. Rocks \& Minerals, 94, 70-83. https://doi.org/10.1080/00357529.2019.1519677

[65] Geier, B. and Ottemann, J. (1970) New Primary Vanadium-, Germanium-, Gallium-, and Tin-Minerals from the $\mathrm{Pb}-\mathrm{Zn}-\mathrm{Cu}-\mathrm{Deposit}$ Tsumeb, South West Africa. Mineralium Deposita, 5, 29-40. https://doi.org/10.1007/BF00207004

[66] Cairncross, B. (2017) Connoisseur's Choice: Leiteite, Tsumeb Mine, Tsumeb, Namibia. Rocks \& Minerals, 92, 264-269.

https://doi.org/10.1080/00357529.2017.1283661 